\title{
LONELINESS, COPING STRATEGIES AND PERCEIVED SOCIAL SUPPORT AMONG STUDENTS OF PUBLIC UNIVERSITIES IN MALAYSIA DURING THE COVID-19 MCO
}

\author{
Siti Haslina Hussin* \\ Faculty of Language and Communication, Universiti Malaysia Sarawak \\ Awang Ideris Awang Daud \\ Faculty of Social Sciences and Humanities, Universiti Malaysia Sarawak \\ Malia Taibi \\ Faculty of Language and Communication, Universiti Malaysia Sarawak \\ Siti Rahayu Hussin \\ Faculty of Economics and Management, Universiti Putra Malaysia
}

\begin{abstract}
The unprecedented COVID-19 pandemic had prompted many governments to enforce lockdown to prevent the virus from spreading. In Malaysia, a series of Movement Control Orders (MCO) were introduced starting March 18, 2020. As a result, many people's lives were affected, including university students. These affected students had to stay in their campus residential facilities, isolated from family, relatives and friends, which could lead to the feeling of loneliness. This study aims to explore the phenomenon among students stranded on campus during MCO periods. Approximately 243 students from several public universities were surveyed using Google form. Results from the 210 usable responses showed that most of these students experienced moderate loneliness and often used coping approaches like acceptance, positive interpretation, active coping, and active solitude. Friends seemed to be a more immediate source to seek for support in times of isolation. Correlation results suggested that social support availability is negatively associated with student loneliness experience, and positively related with student coping strategies. Specifically, the availability of support from friends and significant others may minimize loneliness experience.
\end{abstract}

Keywords: Loneliness, Coping Strategies, Social Support, Malaysia, COVID-19

Received: 30 July 2020

Accepted: 11 June 2021

https://doi.org/10.33736/ijbs.4311.2021

\footnotetext{
* Corresponding author: Faculty of Language and Communication, Universiti Malaysia Sarawak, Tel: +082-582643; Email: hhaslina@unimas.my
} 


\section{INTRODUCTION}

Due to the outbreak of COVID-19, the then Malaysian Prime Minister, Tan Sri Muhyiddin Yassin announced the 14-day Movement Control Order (MCO) on March 16, 2020. The MCO is similar to the lockdown or circuit breaker introduced in other countries as one of the measures taken to contain the transmission of the COVID-19 virus. During the MCO, non-essential businesses, stores, schools, institutions of higher learning and houses of worship were ordered to suspend operations. While most Malaysians were forced to stay at home, around 60,000 students were stranded on campus. They were only allowed to return home gradually starting $27^{\text {th }}$ April 2020 . The unprecedented MCO enforcement has affected these students' social lives due to strict distancing policies. For the first time, they were experiencing an unexpected separation from important people and activities of their lives.

This study examined the experience of university students stranded on campus during MCO, where physical interactions were limited and communications were mainly based on the Internet connection. Bu et al. (2020) suggested students have a higher risk of experiencing loneliness during the lockdown than usual. The experience of loneliness was due to lockdown stressors. These stressors include separation from family and friends, loss of independence, doubts about the virus spread, the duration of lockdown, resentment, monotonous lifestyle, potential scarcity of essential goods, lack of accurate information, monetary loss, and stigma (Sundarasen et al., 2020). During the pandemic, loneliness can also turn into stress and other psychological impacts on the affected people. Hawryluck et al. (2004) reported that those who have gone into quarantine experience to be predictive of subsequent general psychological distress. Buecker et al. (2020) revealed that those with higher odds of being lonely are young adults, women, people with lower education or income, the economically inactive, people living alone, and urban residents.

Coping abilities and social support were identified as protective factors against adversity and stressful conditions such as disaster situations and disease outbreaks (Yu et al., 2020). Coping strategies refer to the specific behavioural and psychological efforts that people employ to tolerate, reduce, or minimize stressful events (Noorbakhsh et al., 2010). Xu et al. (2020) stated that social support is one of the most important general resistance resources, which could prompt people to perceive their lives as predictable, controllable, and understandable, thus performing more adaptively in stressful situations. Adequate peers and family support is vital to assist an individual in effectively managing stress-provoking situations such as disaster events, emergency crises, and infectious disease outbreaks (Langan et al., 2017).

Despite various reports, studies on loneliness during the pandemic remain less anticipated. Nevertheless, studies on loneliness during lockdown due to Covid-19 are relevant because this pandemic is a worldwide outbreak and is considered a major stressful event. The mandatory lockdown imposed by the government has significantly disrupted social activities. Brodeur et al. (2021) suggested that the lockdown has affected people mentally, including being lonely, bored, and sad. In addition, Khoshaim et al. (2020a) revealed that the switch to the unprecedented virtual learning experiences has resulted in major psychological challenges for students.

This study examines the university students' experience of loneliness while being forced to be separated from family, friends, and significant others during the lockdown period. Therefore, this 
study investigates the level of loneliness experienced by the students, their coping strategies in combating loneliness, and sources of social support received while stranded on campus.

This paper contains five sections. This section introduces the study in general. Section 2 describes the concept of loneliness and its different measures as well as coping strategies. Section 3 describes the survey, which comprises questions on the level of loneliness, coping strategies and perceived social supports. Section 4 presents results obtained and discussions according to the objectives of the study. Section 5 concludes the paper with the limitations of the study and suggestions for future research.

\section{LITERATURE REVIEW}

\subsection{Loneliness}

Loneliness is a phenomenon that belongs to life and existence. To one person, loneliness can be experienced differently at different times and circumstances. As loneliness involves social isolation, Public Health England defines loneliness as an individual's personal, subjective sense of lacking connection and contact with social interactions to the extent that they feel not wanted or needed (Sanders, 2020). Achterbergh et al. (2020) claimed loneliness as a negative emotional state that arises when there is a perceived discrepancy between desired and actual social relationships.

Literature has confirmed the significant prevalence of loneliness amongst university students worldwide, mainly due to uncertainties in the environment such as 'cultural shock' and during a pandemic. Hysing et al. (2020) mentioned an increase of loneliness incidence among university students in Norway. Özdemir and Tuncay (2008) studied the level of loneliness, essential needs during university education, and relationships between loneliness, essential needs, and characteristics of university students in Turkey. Bauer and Rokach (2004) found a rather consistent pattern of differences of experience of loneliness between the Canadian and Czechs students based on their cultural backgrounds. Scholars also examined the factors influencing and causing loneliness among university students (Dagnew \& Dagne, 2019; Pijpers, 2017; Ramos, 2020). Women experience deteriorating mental well-being more than men during the Covid-19 pandemic (Etheridge \& Spantig, 2020). Bek (2017) assessed the effect of loneliness on academic participation and success among 213 students studying at Usak University. Some studies investigated the relationship between coping strategies and loneliness among college students (Besse, 2016; O’Donovan \& Hughes, 2007; Vasileiou et al., 2019).

Loneliness can be a unidimensional or multidimensional concept. Some researchers view loneliness as a single occurrence that varies in its intensity. Alternatively, loneliness is also seen as multidimensional concepts. Weiss (1973, as cited in Coşan, 2014) categorized loneliness into two dimensions, namely social and emotional dimensions. Social loneliness occurs when a person does not have a wider social network as desired whereas emotional loneliness occurs when someone is missing an intimate relationship. Emotional loneliness can result in distress and apprehension (Wang et al., 2018). As a type of loneliness, internal loneliness comes from a perception of being alone in any situation. Factors associated with internal loneliness include personality, locus of control, mental distress, low self-esteem, guilt feeling, and poor coping strategies with situations (Mushtaq et al., 2014). The experience of loneliness can also be viewed 
between state and trait experiences of loneliness. State loneliness is temporary and occurs because of situational factors such as being away from family members, friends or significant others (Van Winkel et al., 2017). In contrast, trait loneliness refers to consistent feeling lonely like feel persistently feeling unhappy with their relationships over a long period of time.

\subsection{Coping Strategies}

The perception of loneliness and coping with it vary among individuals and cultural groups (deJong Gierveld \& Fokkema, 2015). Coping is process-oriented that refers to one's changing cognitive and behavioral efforts to manage external and internal demand, which depends on context and preferences (Schoenmaker et al., 2015, as cited in Rokach, 2018). Individuals will seek various approaches to deal with loneliness. Rokach (2018) suggested six dimensions of coping strategies of loneliness: acceptance and reflection, solitude, self-development and understanding, social support network, distancing, denial, and connecting to religion and faith.

Literature on strategies to reduce loneliness also suggests a relationship between using the Internet and loneliness (Seepersad, 2001; Sum et al., 2008). Consistent with Nowland et al. (2018), during the COVID-19 lockdown, people might have been motivated to reach out to others remotely via the Internet to help them reduce the feeling of loneliness. Khoshaim et al. (2020b) reported that the young generation of Saudi Arabia focused their energy on alternative activities online, like developing new hobbies, sharing hobbies with friends through social media channels, being proactive and even creating jokes and sarcastic comments about the situation they were facing.

Thus, it is hypothesized that:

\section{H1: There is a significant linear association between coping strategies and experience of loneliness}

\subsection{Social Support}

Social support is defined as the existence or availability of people on whom one can rely on and from whom one can experience care, value, and love. Ye et al. (2014, as cited in Ren and Ji, 2019) proposed that perceived social support as a level of satisfaction individuals feel, which include respect, understanding, and support that they perceive in their living environment. Researchers identify social support, personal resilience, and coping abilities as protective factors against adversity and stressful conditions such as disease outbreaks (Labrague et al., 2020).

Park et al. (2013) suggested that perceived social support can reduce the incidence of mental illness, such as loneliness. Loneliness and perceived social support were found to be negatively associated (Wang et al., 2018). Individuals reporting greater perceived social support also reported less loneliness (Segrin \& Passalacqua, 2010). Sarason et al. (1990, as cited in Hombrados et al., 2013) have classified social support into four subtypes: emotional, instrumental, appraisal, and informational support. Perceived social support from family, friends and romantic partners are instrumental in the association between stress and loneliness (Lee \& Goldstein, 2016). In short, the magnitude of the relationship between stress and loneliness of youth with higher levels of support from friends was less than those with a lower level of support from friends. 
Thus, it is hypothesized that:

\section{H2: There is a significant linear association between perceived social support and experience of loneliness}

Figure 1 shows the study model showing the hypothesized relationships among the variables.

\section{Figure 1: Study Model}

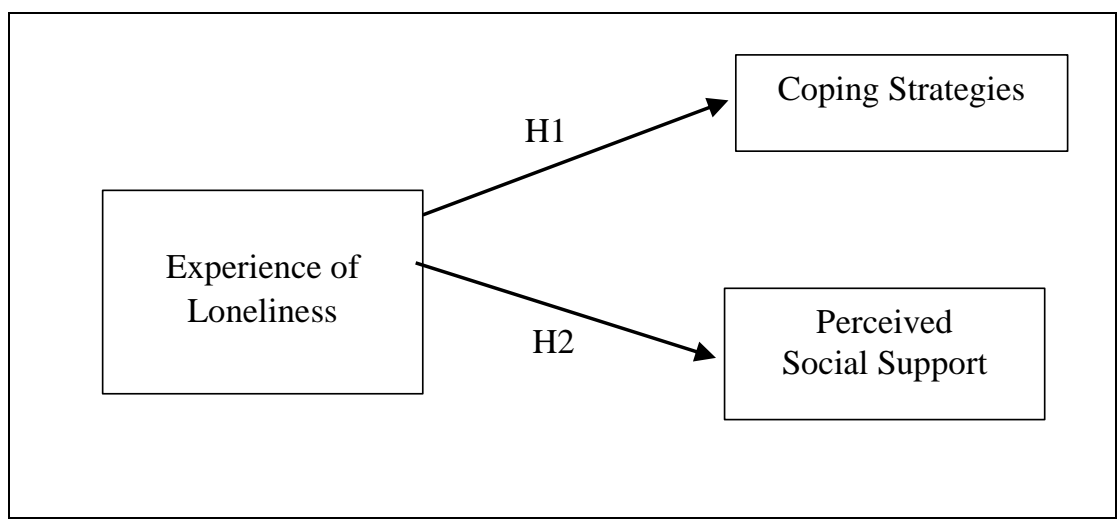

\section{METHODOLOGY}

This study adopted a positivistic approach that utilizes the survey method. The population of this study include the undergraduate students stranded on campus during the first MCO in Malaysia. As of $24^{\text {th }}$ April 2020, the Ministry of Higher Education (MOHE) of Malaysia reported that about 60,950 students were stranded on campus residential facilities. Given this population size, the suggested sample size, according to Krejcie and Morgan (1970), was about 384. Ideally, the probability sampling approach would be most appropriate in this instance. However, because the sampling frame was absent, as suggested by Saunders et al. (2016) and Zikmund-Fisher et al. (2012), the researchers had to use their judgement to select cases that best address their research objectives. The key criterion for choosing the respondent is strictly limited to those staying at residential college.

About 500 sets of Google survey forms were distributed to the prospective respondents. Only 243 sets of the forms were timely returned, giving a response rate of about $48.6 \%$. Despite being less than 384, this response rate is considered reasonable for online surveys (Nulty, 2008). The data collection activity was confined to a duration of 39 days only, from 18 March 2020 until 27 April 2020. After 27 April 2020, the restriction was relaxed, and the stranded students were allowed to leave campus and returned to their respective hometowns. Hence, responses received after 27 April 2020 were excluded from this study to avoid contamination of the data.

Out of the 243 responses, 210 were complete and suitable for analysis. Table 1 summarizes the profiles of respondents. About $70 \%$ of the respondents are males and $30 \%$ females, and about $88 \%$ 
of them aged between 21 to 25 years old. More than half of the respondents hailed from Sabah and Sarawak, and the rest were from the Peninsular Malaysia. About 82 respondents or 39\% reported staying alone during the MCO periods, whereas 128 of them had roommates at least a person. The three common reasons for these students being stranded on campus facilities were the unavailability of transport or flights to return to hometown, abide by the MCO periods, and no plan to return home during the mid-semester break, when at the same time the MCO periods were imposed.

Table 1: Profiles of Respondents

\begin{tabular}{|c|c|c|}
\hline Characteristics & Frequency & Percentage \\
\hline \multicolumn{3}{|l|}{ Gender } \\
\hline Male & 63 & 30 \\
\hline Female & 147 & 70 \\
\hline Total & 210 & 100.0 \\
\hline \multicolumn{3}{|l|}{ Age } \\
\hline$\leq 20$ & 17 & 8.1 \\
\hline $21-25$ & 185 & 88.1 \\
\hline$\geq 26$ & 8 & 3.8 \\
\hline Total & 210 & 100.0 \\
\hline \multicolumn{3}{|l|}{ Hometown/Region of Origin } \\
\hline Peninsular Malaysia & 94 & 44.8 \\
\hline Sabah & 58 & 27.6 \\
\hline Sarawak & 58 & 27.6 \\
\hline Total & 210 & 100.0 \\
\hline \multicolumn{3}{|l|}{ Number of Roommates } \\
\hline Alone & 82 & 39.0 \\
\hline 1 & 45 & 21.4 \\
\hline 2 & 25 & 11.9 \\
\hline 3 & 23 & 11.0 \\
\hline 4 or more & 35 & 16.7 \\
\hline Total & 210 & 100.0 \\
\hline \multicolumn{3}{|l|}{ Reason for Staying on Campus } \\
\hline Stranded (no transport/flight) & 17 & 8.1 \\
\hline Worry about travelling & 3 & 1.4 \\
\hline No plan to return home during semester break & 26 & 12.4 \\
\hline Abide to Movement Control Order & 22 & 10.5 \\
\hline More conducive and safer than own home & 7 & 3.3 \\
\hline Nowhere to go & 2 & 1.0 \\
\hline Other & 6 & 2.9 \\
\hline Missing data (nonresponse) & 127 & 39.5 \\
\hline Total & 210 & 100.0 \\
\hline
\end{tabular}

The experience of loneliness was measured using 11 items adapted from de Jong Gierveld (1987) that comprises five dimensions. The items were anchored to a 5-point scale with $1=$ never feel this way and $5=\mathrm{I}$ feel this way all the time. With six items reverse-coded, the reliability of the measure of experience of loneliness was 0.713. To compute the levels of loneliness, all the eleven items measuring the state of loneliness were added up, giving the range of possible scores between 11 and 55. These scores were then divided into three categories indicating low, moderate and high levels of loneliness respectively, with an interval of 14.7 points for each category. 
Coping strategies were measured using 31 items adapted from three sources: Zelin et al. (1983), COPE scale (Carver et al., 1989) and, Rubenstein and Shaver Reactions to Loneliness Measure (1982). The items were anchored to a 5-point agreement scale with $1=$ strongly disagree, and 5= strongly agree. Measuring coping strategies was considered reliable with 0.876 Cronbach alpha indicating the suitability of the items used.

A total of 12 items were used to measure perceived social support for the students that were adapted from Zimet et al. (1988). The items represent three major sources of social support, including special person, family, and friends. The responses were fixed to a 5-point agreement scale with 1 $=$ strongly disagree and $5=$ strongly agree. The internal consistency of the measure was 0.928 .

Prior to the actual survey, the form was pre-tested among 10 students, who met the target sample criteria. Feedback and comments from these students were considered to improve the instrument. To achieve the objectives of the research, descriptive statistics were generated from the data to describe the profile of respondents, level of experience of loneliness, coping strategies, and perceived social supports. Since the three constructs in the study were measured by ordinal and Likert scale, to measure the linear association between the ranks of the variables of coping strategies, perceived social supports and experience of loneliness, the Spearman Rho correlations were computed.

\section{RESULTS AND DISCUSSION}

\subsection{Level of loneliness experienced by undergraduate students}

The first objective of this study was to investigate and measure the level of loneliness experienced by undergraduate students stranded on campus. Table 2 summarizes the feeling of loneliness described by the means, standard deviations, frequencies, and percentages. Five dimensions (Severe Deprivation, Deprivation Feelings Connected with Specific Problem Situations, Missing Companionship, A Feeling of Sociability, and A Feeling of Having Meaningful Relationships) were used to gauge the extent of the feeling of loneliness experienced by students. The mean score of students experiencing loneliness is 3.03. However, the breakdowns by dimension have shown different patterns of responses. The item "I experience a general sense of emptiness) scored a mean value of 3.14, which is higher than "I often feel rejected" (2.62) in the Severe Deprivation dimension. In Deprivation Feelings Connected with Specific Problem Situation dimension, the mean score for "I miss having people around me" is 3.52. The highest mean score for Missing Companionship dimension came from the item "I miss the pleasure of the company of others" (3.42). In A Feeling of Sociability dimension, the item "There is always someone I can talk to about my day-to-day problems" scored a mean value of 2.54. The item "There are many people I can trust completely" scored a mean of 3.20, which is the highest mean value in Feeling of Having Meaningful Relationships dimension. 
Table 2: Feeling of Loneliness: Means, Standard Deviations, Frequencies and Percentages (in parentheses) $(\mathrm{n}=210)$

\begin{tabular}{|c|c|c|c|c|c|c|c|}
\hline & Mean & S.D. & 1 & 2 & 3 & 4 & 5 \\
\hline \multicolumn{8}{|l|}{ Severe Deprivation } \\
\hline I often feel rejected. & 2.62 & 1.289 & $\begin{array}{c}47 \\
(22.4)\end{array}$ & $\begin{array}{c}62 \\
(29.5)\end{array}$ & $\begin{array}{c}49 \\
(23.3)\end{array}$ & $\begin{array}{c}27 \\
(12.9)\end{array}$ & $\begin{array}{c}25 \\
(11.9)\end{array}$ \\
\hline $\begin{array}{l}\text { I experience a general sense } \\
\text { of emptiness. }\end{array}$ & 3.14 & 1.194 & $\begin{array}{c}23 \\
(11.0)\end{array}$ & $\begin{array}{c}34 \\
(16.2)\end{array}$ & $\begin{array}{c}76 \\
(36.2)\end{array}$ & $\begin{array}{c}44 \\
(21.0)\end{array}$ & $\begin{array}{c}33 \\
(15.7)\end{array}$ \\
\hline \multicolumn{8}{|c|}{ Deprivation Feelings Connected with Specific Problem Situations } \\
\hline $\begin{array}{l}\text { I miss having people around } \\
\text { me }\end{array}$ & 3.52 & 1.246 & $\begin{array}{c}16 \\
(7.6)\end{array}$ & $\begin{array}{c}32 \\
(15.2)\end{array}$ & $\begin{array}{c}44 \\
(21.0)\end{array}$ & $\begin{array}{c}62 \\
(29.5)\end{array}$ & $\begin{array}{c}56 \\
(26.7)\end{array}$ \\
\hline \multicolumn{8}{|l|}{ Missing Companionship } \\
\hline $\begin{array}{l}\text { I find my circle of friends and } \\
\text { acquaintances too limited. }\end{array}$ & 3.18 & 1.250 & $\begin{array}{c}22 \\
(10.5)\end{array}$ & $\begin{array}{c}45 \\
(21.4)\end{array}$ & $\begin{array}{c}54 \\
(25.7)\end{array}$ & $\begin{array}{c}52 \\
(24.8)\end{array}$ & $\begin{array}{c}37 \\
(17.6)\end{array}$ \\
\hline $\begin{array}{l}\text { I miss having a really close } \\
\text { friend. }\end{array}$ & 3.41 & 1.208 & $\begin{array}{c}13 \\
(6.2)\end{array}$ & $\begin{array}{c}33 \\
(15.7)\end{array}$ & $\begin{array}{c}74 \\
(35.2)\end{array}$ & $\begin{array}{c}35 \\
(16.7)\end{array}$ & $\begin{array}{c}55 \\
(26.2)\end{array}$ \\
\hline $\begin{array}{l}\text { I miss the pleasure of the } \\
\text { company of others }\end{array}$ & 3.42 & 1.139 & $\begin{array}{l}13 \\
(6.2)\end{array}$ & $\begin{array}{c}30 \\
(14.3)\end{array}$ & $\begin{array}{c}64 \\
(30.5)\end{array}$ & $\begin{array}{c}62 \\
(29.5)\end{array}$ & $\begin{array}{c}41 \\
(19.5)\end{array}$ \\
\hline \multicolumn{8}{|l|}{ A Feeling of Sociability } \\
\hline $\begin{array}{l}\text { There is always someone I } \\
\text { can talk to about my day-to- } \\
\text { day problems. }\end{array}$ & 2.54 & 1.162 & $\begin{array}{c}47 \\
(22.4)\end{array}$ & $\begin{array}{c}58 \\
(27.6)\end{array}$ & $\begin{array}{c}63 \\
(30.0)\end{array}$ & $\begin{array}{c}29 \\
(13.8)\end{array}$ & $\begin{array}{c}13 \\
(6.2)\end{array}$ \\
\hline \multicolumn{8}{|c|}{ A Feeling of Having Meaningful Relationships } \\
\hline $\begin{array}{l}\text { There are plenty of people I } \\
\text { can lean on when I have } \\
\text { problems. }\end{array}$ & 2.80 & 1.141 & $\begin{array}{c}31 \\
(14.8)\end{array}$ & $\begin{array}{c}54 \\
(25.7)\end{array}$ & $\begin{array}{c}67 \\
(31.9)\end{array}$ & $\begin{array}{c}43 \\
(31.9)\end{array}$ & $\begin{array}{c}15 \\
(7.1)\end{array}$ \\
\hline $\begin{array}{l}\text { There are enough people I } \\
\text { feel close to. }\end{array}$ & 2.69 & 1.205 & $\begin{array}{c}35 \\
(16.7)\end{array}$ & $\begin{array}{c}70 \\
(33.3)\end{array}$ & $\begin{array}{c}51 \\
(24.3)\end{array}$ & $\begin{array}{c}34 \\
(16.2)\end{array}$ & $\begin{array}{c}20 \\
(9.5)\end{array}$ \\
\hline $\begin{array}{l}\text { I can call on my friends } \\
\text { whenever I need them. }\end{array}$ & 2.81 & 1.280 & $\begin{array}{c}37 \\
(17.6)\end{array}$ & $\begin{array}{c}55 \\
(26.2)\end{array}$ & $\begin{array}{c}58 \\
(27.6)\end{array}$ & $\begin{array}{c}31 \\
(14.8)\end{array}$ & $\begin{array}{c}29 \\
(13.8)\end{array}$ \\
\hline $\begin{array}{l}\text { There are many people I can } \\
\text { trust completely. }\end{array}$ & 3.20 & 1.145 & $\begin{array}{c}19 \\
(9.0)\end{array}$ & $\begin{array}{c}35 \\
(17.7)\end{array}$ & $\begin{array}{c}68 \\
(32.4)\end{array}$ & $\begin{array}{c}60 \\
(28.6) \\
\end{array}$ & $\begin{array}{c}28 \\
(13.3)\end{array}$ \\
\hline
\end{tabular}

Table 3 shows that majority of the students experienced a moderate level of loneliness, which involved 150 or $71.4 \%$ of them. However, about 29 or $13.8 \%$ of the students reported a low level of loneliness, and around 31 or $14.8 \%$ of them experienced a high level of loneliness.

Table 3: Level of Loneliness $(n=210)$

\begin{tabular}{lcc}
\hline \hline & Frequency & Percent \\
\hline Low & 29 & 13.8 \\
Moderate & 150 & 71.4 \\
High & 31 & 14.8 \\
Total & 210 & 100.0 \\
\hline \hline
\end{tabular}

The level of loneliness was also analyzed according to gender. Table 4 shows that both groups experienced a moderate feeling of loneliness while being stranded on campus. For male students, 
around 7 or $24.1 \%$ experienced a low level of loneliness, as compared to around 22 or $75.9 \%$ of female students. The ratio of female students who experienced a low level of loneliness is three times more than their male counterparts. For the moderate level of loneliness, the percentage of female experiencing a moderate level of loneliness is twice of the male students which comprises of 50 male and 100 female students. Female students scored four times higher than male students when experiencing a high level of loneliness. This is shown by around 25 female students or $80.6 \%$ of them and only 6 or $19.4 \%$ of male students.

The level of loneliness experienced by the students stranded on campus is moderate. It is worth noting that the students rated high for the items that 'they missed the companionship of others' as the interpretation of their loneliness. Loneliness has a negative connotation and is defined as "the unpleasant experience that occurs when a person's network of special relation is deficient in some important way, either quantitatively or qualitatively" (Perlman \& Peplau, 1981, p.31, as cited in de Jong Gierveld, 2015). It is fair to relate the notion of missing the companionship of others during the lockdown because everyone was restricted to close physical contact. Thus, being far from family and friends, the students were not allowed to go out to socialize, but to stay in their dorms. The only connection to the family and friends was via the Internet. They could call and video call in order to feel the companionship when they felt isolated.

Table 4: Level of Loneliness and Gender $(n=210)$

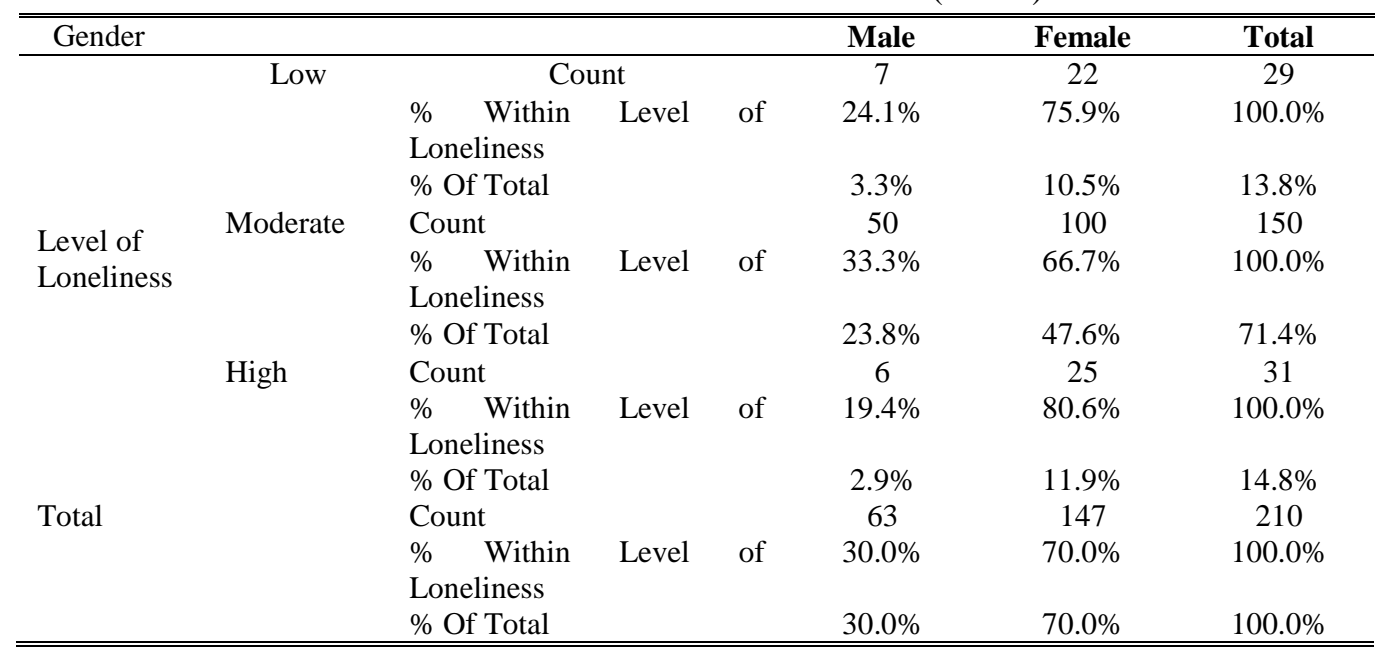

\subsection{Coping strategies adopted by students}

Another objective of this study was to explore the coping strategies adopted by the students experiencing the feeling of loneliness when stranded on campus. Table 5 shows the ranking of the dimensions for coping strategies according to the respective average means scores. 
Table 5: Coping Strategies: Dimensions ranking \& Average mean

(In parentheses) $(\mathrm{n}=210)$

\begin{tabular}{lc}
\hline \hline Dimensions & Average Mean \\
\hline Acceptance (1) & 3.17 \\
Positive Reinterpretation (2) & 3.14 \\
Planning (3) & 2.98 \\
Active Coping (4) & 2.90 \\
Active Solitude (5) & 2.89 \\
Instrumental Social Support (6) & 2.72 \\
Mental disengagement (7) & 2.71 \\
Sad Passivity (8) & 2.70 \\
Emotional Social Support (9) & 2.63 \\
Venting of Emotions (10) & 2.26 \\
Behavioral disengagement (11) & 2.07 \\
\hline \hline
\end{tabular}

Based on the eleven dimensions adopted for coping strategies, respondents rated the following as their coping strategies: active coping; planning; instrumental social support; emotional social support; positive reinterpretation; acceptance; behavioural disengagement; venting of emotions; active solitude; sad passivity; and mental disengagement. Table 5 shows that in general, the highest average mean score is 3.17 for the acceptance dimension. The lowest average mean score is the dimension behavioural disengagement (2.07). Respondents usually use acceptance as their main coping strategy and respondents usually do not use behavioural disengagement for coping with loneliness during their stay at the residential facilities on campus. In terms of average mean score, findings show that the frequency of coping strategies from mostly used to not used at all is as follows: (i) acceptance, (ii) positive reinterpretation, (iii) planning, (iv) active coping, (v) active solitude, (vi) instrumental social support, (vii) mental disengagement, (viii) sad passivity, $(x)$ emotional social support, (xi) venting of emotions, and (xii) behavioural disengagement.

However, two items in the active solitude dimension scored the highest mean, with 3.35 and 3.26 respectively for "I work on a hobby, like reading or watching videos to take my mind off things" and "I listen to music to help relieve my loneliness." Mean score was also high $(>3.0)$ for items in the acceptance dimension such as "I can learn to live with it" and items in the positive reinterpretation dimension such as "I look for something good in what is happening" and "I try to see it in a different light, to make it seem more positive." Respondents reported to usually do active coping and planning with a mean score of 2.9 to 3.0 respectively.

Mental disengagement as a coping strategy received mixed reactions from the respondents. While the mean score for "I watch online movies or watch live streaming TV to think about it less" and "I use the Internet when I feel lonely" scored 3.20 and 3.39 respectively, other mental disengagement strategies had low mean scores. "I daydream about things other than this"; "I sleep more than usual"; "I engage in online shopping when I feel lonely"; and "I spend money when I feel lonely". Respondents reported the lowest mean score for mental disengagement, with mean of 2.02 for "I engage in online shopping when I feel lonely" and "I spend money when I feel lonely."

Respondents also rated low for items in the behavioral disengagement dimension with mean of 2.04 and 2.11 respectively for "I give up the attempt to get rid of my loneliness" and "I admit to 
myself that I can't deal with it and quit trying". Findings also show that respondents usually do not vent out emotions as their coping strategies, with mean score of less than 2.5. On the other hand, the mean score for items in the emotional social support, instrumental social support and sad passivity dimensions were between 2.0 and 3.0.

As Nurunnabi et al. (2020) defined a coping strategy as the behaviors, thoughts, and emotions that students use to adjust to the changes that occur in their life during COVID-19, this study shows that the high mean scores for acceptance and positive reinforcement dimensions prove that the students' attitude towards feeling loneliness is positive. As cited in Cheshire et al. (2010), positive reinterpretation has been associated with acceptance coping (Park \& Fenster, 2004), positive affect (Moskowitz et al., 1996) and optimism (Scheier et al., 1994). Believing that being positive is the first thing to encounter every obstacle, the undergraduate students showed that the best strategy to cope with the experience of loneliness is to make themselves to accept the fact they must learn to live with it. Mate (2003, as cited in Rokach, 2018) stipulated that when someone accepts the situation, he or she simply recognizes it and has the willingness to accept how things are. Furthermore, acceptance does not mean that the person must quit any circumstance. It implies that when someone accepts what is there for him or her, he or she is creating a compassionate relationship with himself or herself.

As Malaysians living in the collective cultures, the students diligently obeyed the authority when they were asked to stay on campus during the lockdown. Instead of showing resistance to the directive, the students opted for a positive reinterpretation of the whole experience. They acknowledged the lockdown situation, shifted the bad feelings and were more optimistic in hope to experience positive emotions. Besides being positive, the students used active solitude as one of the coping strategies. Although being stranded on campus restricted their movement, the students made full use of the Internet on campus and regarded it as a "saviour" for them. With the usage of the Internet, they kept themselves busy doing activities that really helped them to reduce the feeling of loneliness. They used the Internet to keep in touch with family and friends, get updated news, listen to music, play online games, watch videos, and even do a little exercise in their room. This finding is congruent with Moore and March (2020) study which revealed that connecting with others via non-face-to-face communication including communications (phone call, messaging) and social media positively predicted engagement in proactive coping behaviours. This is true especially when the students realized that the feeling of loneliness was only temporary. As such, these students were experiencing state loneliness as far as being stranded on campus during the MCO period is concerned.

This study also shows that the two lowest mean score dimensions are behavioural disengagement and venting emotions. Carver, Scheier and Weintraub (1989, as cited in Carver \& Connor-Sminth, 2010), stipulated that behavioural disengagement is one of the two coping tendencies that are believed to be dysfunctional in many circumstances. Respondents clearly showed that they did not give up and quit when they experienced loneliness. As mostly disagreed with the notion of helplessness, the students scored low for the behavioural dimension as to show that they were positive and were aware of their inner strength, resources, and ability to survive despite the anguish of loneliness (Moustakas, 1972 as cited in Rokach, 2018). The low score for the venting of emotions dimension proves that when they have accepted and always positive, the students felt that focusing on emotional distress and letting those emotions could be dysfunctional to reduce loneliness. After all, they had nobody to blame when the lockdown was mandated. Nevertheless, 
believing that they were experiencing state loneliness, these undergraduate students went through their days being stranded on campus with a positive mind.

\subsection{Sources of Social Support}

The third objective of this study is to identify sources of social support available to the students while stranded on campus. There are three main sources of social support that students can get from, namely significant others, family, and friends. Table 6 shows the details of the mean score of sources of social support. Comparing the items in getting support from significant others, the data indicate that the item "there is a special person with whom I can share my joys and sorrows" has the highest mean score of 3.58 whereas the item "there is a special person who is around me when I am in need" scored the lowest mean of 3.50 .

In getting support from family, the item "I can talk about my problems with my family" scores low mean of 3.37, while the highest mean score is from the item "my family really tries to help me" (3.87).

Apart from significant others and family, respondents also receive support from friends. The highest mean score is 3.57 which is "I have friends whom I can share my joys and sorrows" whereas the item "I can talk about my problems with my friends" shows the lowest mean score of 3.27.

Table 6: Sources of Social Support: Means, Standard Deviations, Frequencies \& Percentages (In parentheses), $\mathrm{n}=210$

\begin{tabular}{|c|c|c|c|c|c|c|c|}
\hline & Mean & S.D. & 1 & 2 & 3 & 4 & 5 \\
\hline \multicolumn{8}{|l|}{ SIGNIFICANT OTHERS } \\
\hline $\begin{array}{l}1 \text { There is a special person } \\
\text { who is around when I am } \\
\text { in need. }\end{array}$ & 3.50 & 1.199 & $\begin{array}{c}17 \\
(8.1)\end{array}$ & $\begin{array}{c}20 \\
(9.5)\end{array}$ & $\begin{array}{c}67 \\
(31.9)\end{array}$ & $\begin{array}{c}53 \\
(25.2)\end{array}$ & $\begin{array}{c}53 \\
(25.2)\end{array}$ \\
\hline $\begin{array}{l}2 \text { There is a special person } \\
\text { with whom I can share my } \\
\text { joys and sorrows. }\end{array}$ & 3.58 & 1.220 & $\begin{array}{c}17 \\
(8.1)\end{array}$ & $\begin{array}{c}20 \\
(9.5)\end{array}$ & $\begin{array}{c}57 \\
(27.1)\end{array}$ & $\begin{array}{c}57 \\
(27.1)\end{array}$ & $\begin{array}{c}59 \\
(28.1)\end{array}$ \\
\hline $\begin{array}{l}3 \text { I have a special person } \\
\text { who is a real source of } \\
\text { comfort to me }\end{array}$ & 3.53 & 1.242 & $\begin{array}{c}17 \\
(8.1)\end{array}$ & $\begin{array}{c}24 \\
(11.4)\end{array}$ & $\begin{array}{c}59 \\
(28.1)\end{array}$ & $\begin{array}{c}50 \\
(23.8)\end{array}$ & $\begin{array}{c}60 \\
(28.6)\end{array}$ \\
\hline $\begin{array}{l}4 \text { There is a special person in } \\
\text { my life who cares about } \\
\text { my feelings. }\end{array}$ & 3.54 & 1.230 & $\begin{array}{c}17 \\
(8.1)\end{array}$ & $\begin{array}{c}22 \\
(10.5)\end{array}$ & $\begin{array}{c}61 \\
(29.0)\end{array}$ & $\begin{array}{c}51 \\
(24.3)\end{array}$ & $\begin{array}{c}59 \\
(28.1)\end{array}$ \\
\hline \multicolumn{8}{|l|}{ FAMILY } \\
\hline $\begin{array}{l}\text { 1 My family really tries to } \\
\text {. help me. }\end{array}$ & 3.87 & 1.133 & $\begin{array}{c}11 \\
(5.2)\end{array}$ & $\begin{array}{c}13 \\
(6.2)\end{array}$ & $\begin{array}{c}45 \\
(21.4)\end{array}$ & $\begin{array}{c}65 \\
(31.0)\end{array}$ & $\begin{array}{c}76 \\
(36.2)\end{array}$ \\
\hline $\begin{array}{l}2 \text { I get the emotional help } \\
\text { and support I need from } \\
\text { my family. }\end{array}$ & 3.79 & 1.147 & $\begin{array}{c}11 \\
(5.2)\end{array}$ & $\begin{array}{c}15 \\
(7.1)\end{array}$ & $\begin{array}{c}53 \\
(25.2)\end{array}$ & $\begin{array}{c}59 \\
(28.1)\end{array}$ & $\begin{array}{c}72 \\
(34.3)\end{array}$ \\
\hline $\begin{array}{l}3 \text { I can talk about my } \\
\text { problems with my family. }\end{array}$ & 3.37 & 1.310 & $\begin{array}{c}25 \\
(11.9)\end{array}$ & $\begin{array}{c}25 \\
(11.9)\end{array}$ & $\begin{array}{c}63 \\
(30.0)\end{array}$ & $\begin{array}{c}42 \\
(20.0)\end{array}$ & $\begin{array}{c}55 \\
(26.2)\end{array}$ \\
\hline $\begin{array}{l}4 \text { My family is willing to } \\
\text {. help me make decisions }\end{array}$ & 3.68 & 1.141 & $\begin{array}{c}13 \\
(6.2)\end{array}$ & $\begin{array}{c}15 \\
(7.1)\end{array}$ & $\begin{array}{c}58 \\
(27.6)\end{array}$ & $\begin{array}{c}65 \\
(31.0)\end{array}$ & $\begin{array}{c}59 \\
(28.1)\end{array}$ \\
\hline
\end{tabular}




\begin{tabular}{|c|c|c|c|c|c|c|c|}
\hline \multicolumn{8}{|l|}{ FRIENDS } \\
\hline $\begin{array}{l}1 \text { My friends really try to } \\
\text { help me. }\end{array}$ & 3.44 & 1.066 & $\begin{array}{c}13 \\
(6.2)\end{array}$ & $\begin{array}{c}21 \\
(10.0)\end{array}$ & $\begin{array}{c}70 \\
(33.3)\end{array}$ & $\begin{array}{c}73 \\
(34.8)\end{array}$ & $\begin{array}{c}33 \\
(15.7)\end{array}$ \\
\hline $\begin{array}{l}2 \text { I can count on my friends } \\
\text { when things go wrong. }\end{array}$ & 3.37 & 1.046 & $\begin{array}{l}13 \\
(6.2)\end{array}$ & $\begin{array}{c}21 \\
(10.0)\end{array}$ & $\begin{array}{c}82 \\
(39.0)\end{array}$ & $\begin{array}{c}64 \\
(30.5)\end{array}$ & $\begin{array}{c}30 \\
(14.3)\end{array}$ \\
\hline $\begin{array}{l}3 \text { I have friends with whom } \\
\text { I can share my joys and } \\
\text { sorrows }\end{array}$ & 3.57 & 1.080 & $\begin{array}{c}10 \\
(4.8)\end{array}$ & $\begin{array}{c}20 \\
(9.5)\end{array}$ & $\begin{array}{c}67 \\
(31.9)\end{array}$ & $\begin{array}{c}67 \\
(31.9)\end{array}$ & $\begin{array}{c}46 \\
(21.9)\end{array}$ \\
\hline $\begin{array}{l}4 \text { I can talk about my } \\
\text {. problems with my friends }\end{array}$ & 3.27 & 1.126 & $\begin{array}{c}21 \\
(10.0)\end{array}$ & $\begin{array}{c}19 \\
(9.0)\end{array}$ & $\begin{array}{c}78 \\
(37.1)\end{array}$ & $\begin{array}{c}63 \\
(30.0)\end{array}$ & $\begin{array}{c}29 \\
(13.8)\end{array}$ \\
\hline
\end{tabular}

Table 7 explains the details of correlations data that reveals the associations between experience of loneliness, coping strategies and availability of social supports among the students stranded in campus.

Table 7: Means, Standard Deviations, Scale Reliabilities, and Spearman Rho Correlations Among Key Variables, $(n=210)$

\begin{tabular}{|c|c|c|c|c|c|c|c|c|}
\hline & $\mathrm{M}$ & SD & 1 & 2 & 3 & 4 & 5 & 6 \\
\hline $\begin{array}{l}\text { Experience of } \\
\text { Loneliness } \\
\text { (general) }\end{array}$ & 3.03 & 0.65 & $(0.713)$ & & & & & \\
\hline $\begin{array}{l}\text { Coping Strategies } \\
\text { (general) }\end{array}$ & 2.70 & 0.43 & -.044 & $(0.876)$ & & & & \\
\hline $\begin{array}{l}\text { Perceived Social } \\
\text { Support (general) }\end{array}$ & 3.54 & 0.86 & $-.266^{* *}$ & $.348^{* *}$ & (0.928) & & & \\
\hline $\begin{array}{l}\text { Support from } \\
\text { special person }\end{array}$ & 3.54 & 1.10 & $-.146^{* *}$ & $.365^{* *}$ & $831^{* *}$ & (0.923) & & \\
\hline $\begin{array}{l}\text { Support from } \\
\text { family }\end{array}$ & 3.68 & 1.07 & $-.212^{* * *}$ & $.245^{* *}$ & $.812^{* * *}$ & $.477^{* *}$ & $(0.837)$ & \\
\hline $\begin{array}{l}\text { Support from } \\
\text { friends }\end{array}$ & 3.41 & 0.93 & $-.308^{* * *}$ & $.276^{* *}$ & $.826^{* *}$ & $.602^{* *}$ & $.531^{* *}$ & $(0.882)$ \\
\hline
\end{tabular}

The Spearman Rho coefficients $(r)$ were conducted to examine the linear associations between experience of loneliness, coping strategies and perceived social supports among students stranded on campus. Table 7 shows the associations between perceived social support as a whole and experience of loneliness and coping strategies were statistically significant, $r=-.266, p<0.01$, and $r=.348, p<0.01$ respectively. These results suggest that the availability of social support is negatively associated with students' experience of loneliness. Students who have a higher level of social support, reported relatively lower level of loneliness. Moreover, the availability of social support is positively associated with students' coping strategies. Hence, advocating that stranded students on campus who get more social supports are likely to cope better with their feeling of loneliness.

As discussed earlier, the three main sources of social support are significant others, family, and friends. To understand further about the roles played by these three sources relating to experiences of loneliness, separate correlations between each of the sources of social support were generated. 
Comparatively, roles of availability of social support for students stranded on campus differ between sources (i.e., special person, family, and friends). Although all three sources demonstrate statistically significant associations with experience of loneliness, their magnitudes of connection differ. Among the three sources of social supports, availability of support from friends $(r=.308, p$ $<0.001$ ) shows the strongest association with the experience of loneliness. The support from a special person $(r=.365, p<0.001)$ has the strongest association with students' coping strategies to combat loneliness during the stranded periods.

Although the level of loneliness among students stranded on campus is moderate and seems to indicate that they coped well, it is relevant to discuss the findings regarding perceived social support they received during that time. Focusing on three main sources of social support, it is interesting to note that the students selected different sources for different needs. Lee and Goldstein (2016) confirmed that social support helps individuals uphold their strength, especially when they experience vulnerability in life. Family is considered as the most sought source when it comes to emotional help and support. Students also received support from family when they needed to make decision. This clearly shows that parental and family support remains critical to young adults' wellbeing, including social or interpersonal relationships. However, it is also interesting to point out that the students chose significant others and friends when they needed support to share their feelings. Peer relationships (relationships with friends or intimate partners) play a prominent role in young adults. Thus, when the students indicated higher mean values for the items "There is a special person / I have friends with whom I can share my joys and sorrows," it suggests that they experienced the transition to adulthood, in which they gradually replaced their parents to friends or romantic partners to support their feelings.

\section{CONCLUSION}

The objectives of this study are to examine the level of loneliness experienced by undergraduate university students, their coping strategies and perceived social support received. Results have shown a moderate level of state loneliness. To cope with the feeling of loneliness, those students adopted various coping strategies such as by positively accepting the fact that they have to be temporarily lonely during the MCO periods. As for social support, friends were considered as relatively more sought after as compared to family and significant others.

With reference to the impact of the quadruple helix, this study has demonstrated the impact on university, social and public environment in the case of loneliness among university students during the MCO periods in Malaysia. It is evident that the adoption of technology such as social media has a positive impact on the coping strategies adopted by the students to survive the MCO periods. This leads to the conclusion that it is high time that public universities must not only provide the right technological platform for learning and teaching purposes but must also upgrade the university's system and environment in creating a cohesive and advanced technologically friendly environment that supports students' life in universities. Good internet access at all locations throughout the university is now a must. Government incentives and support to provide the right funding for public universities to enable a holistic infrastructure at all levels must be provided on campus and in dormitories throughout the university. The future is 'smart-university' and 'smart-campus' for a sustainable and world-class education among public universities in Malaysia. 
Overall, this study contributes to the body of knowledge regarding one psychological issue (loneliness) faced by the youth population (undergraduate university students) during an unprecedented world health pandemic in 2020. A better understanding of the mental state of the youth is crucial as it also leads to the understanding of coping strategies needed to minimize the feeling of loneliness. Practically, the government and the universities must give priority to the infrastructure and physical facilities as well as psychological support to university students to ensure their physical and mental health during their lives in the university.

However, this study has its limitations. The sample for this study is limited to local undergraduate students from several universities in Malaysia. Without the participation of international students residing in local universities during the MCO periods, the findings could be different considering the cultural influence on experience and coping strategies of loneliness among them. Future studies may include international students' perspectives regarding loneliness during the world health pandemic. Nonetheless, this study conducted few descriptive analyses with correlations findings to deduce the students' loneliness issues. Further analysis to test the relationship between the variables may be necessary. Future research is also recommended to investigate other different effects of Covid-19, such as anxiety, and the contribution of m-learning through online as one of the ways for coping with these mental health issues.

\section{REFERENCES}

Achterbergh, L., Pitman, A., Birken, M., Pearce, E., Sno, H., \& Johnson, S. (2020). The experience of loneliness among young people with depression: a qualitative meta-synthesis of the literature. BMC psychiatry, 20(1), 1-23.

Bek, H. (2017). Understanding the Effect of Loneliness on Academic Participation and Success among International University Students. Journal of Education and Practice, 8(14), 4650.

Bauer, N. \& Rokach, A. (2004). The Experience of Loneliness in University: A Cross-Cultural Study. International Journal of Adolescence and Youth, 11(4), 283-302.

Besse, R, D. (2016). Loneliness among college students: examining potential coping strategies and the influence of targeted messages on the likelihood of befriending (Unpublished doctoral thesis). Kansas State University, USA.

Brodeur, A., Clark, A. E., Fleche, S., \& Powdthavee, N. (2021). COVID-19, lockdowns, and wellbeing: Evidence from Google Trends. Journal of Public Economics, 193, 104346.

Bu, F., Steptoe, A., \& Fancourt, D. (2020). Loneliness during a strict lockdown: Trajectories and predictors during the COVID-19 pandemic in 38,217 United Kingdom adults. Social Science \& Medicine, 265, 113521.

Buecker, S., Horstmann, K. T., Krasko, J., Kritzler, S., Terwiel, S., Kaiser, T., \& Luhmann, M. (2020). Changes in daily loneliness for German residents during the first four weeks of the Covid-19 pandemic. Social Science and Medicine, 265, 113541.

Carver, C. S., \& Connor-Smith, J. (2010). Personality and coping. Annual review of psychology, 61, 679-704.

Carver, C. S., Scheier, M. F., \& Weintraub, J. K. (1989). Assessing coping strategies: A theoretically based approach. Journal of Personality and Social Psychology, 56(2), 267283. 
Cheshire, A., Barlow, J., \& Powell, L. (2010). Coping using positive reinterpretation in parents of children with cerebral palsy. Journal of Health Psychology, 15(6), 801-810.

Coşan, D. (2014). An evaluation of loneliness. The European Proceedings of Social \& Behavioural Sciences, 1, 103-110.

Dagnew, B., \& Dagne, H. (2019). Year of study as predictor of loneliness among students at University of Gondar. BMC research notes, 12(1), 1-6.

de Jong-Gierveld, J. (1987). Developing and testing a model of loneliness. Journal of personality and social psychology, 53(1), 119.

de Jong Gierveld, J., \& Fokkema, T. (2015). Strategies to Prevent Loneliness. In A. Sha'ked, \& A. Rokach (Eds.), Addresssing loneliness: coping, prevention and clinical interventions (pp. 218-230). Rutledge, New York: Psychology Press.

Etheridge, B., \& Spantig, L. (2020). The gender gap in mental well-being during the Covid-19 outbreak: Evidence from the UK (No. 2020-08). ISER Working Paper Series.

Hawryluck, L., Gold, W. L., Robinson, S., Pogorski, S., Galea, S., \& Styra, R. (2004). SARS control and psychological effects of quarantine, Toronto, Canada. Emerging infectious diseases, 10(7), 1206.

Hombrados-Mendieta, I., García-Martín, M. A., \& Gómez-Jacinto, L. (2013). The relationship between social support, loneliness, and subjective well-being in a Spanish sample from a multidimensional perspective. Social indicators research, 114(3), 1013-1034.

Hysing, M., Petrieb, K., Bøea, T., Lønningcd. K., \& Sivertsenefg, B. (2020). Only the Lonely: A Study of Loneliness Among University Students. Clinical Psychology in Europe, 2(1), 116.

Khoshaim, H. B., Al-Sukayt, A., Chinna, K., Nurunnabi, M., Sundarasen, S., Kamaludin, K., \& Hossain, S. F.A. (2020a). Anxiety Level of University Students During COVID-19 in Saudi Arabia. Frontiers in Psychiatry, 11, 579750.

Khoshaim, H. B., Al-Sukayt, A., Chinna, K., Nurunnabi, M., Sundarasen, S., Kamaludin, K., \& Hossain, S. F. A. (2020b). How students in the Kingdom of Saudi Arabia are coping with COVID-19 pandemic. Journal of Public Health Research, 9 (Suppl 1), 1898.

Krejcie, R.V., \& Morgan, D. W. (1970). Determining Sample Size for Research Activities. Educational and Psychological Measurement, 30, 607-610.

Labrague, L. J., De los Santos, J. A., \& Falguera, C. (2020). Social and emotional loneliness among college students during the COVID-19 pandemic: the predictive role of coping behaviours, social support, and personal resilience. Perspectives in Psychiatric Care, 57(4), 15781584.

Langan, J. C., Lavin, R., Wolgast, K. A., \& Veenema, T. G. (2017). Education for developing and sustaining a health care workforce for disaster readiness. Nursing Administration Quarterly, 41(2), 118-127.

Lee, C. Y. S., \& Goldstein, S. E. (2016). Loneliness, stress, and social support in young adulthood: Does the source of support matter? Journal of youth and adolescence, 45(3), 568-580.

Moore, K. A., \& March, E. (2020). Socially Connected during COVID-19: Online social connections mediate the relationship between loneliness and positive coping strategies. Research Square, 1-14

Moskowitz, J. T., Folkman, S., Collette, L., \& Vittinghoff, E. (1996). Coping and mood during AIDS-related caregiving and bereavement. Annals of Behavioral Medicine, 18(1), 49-57.

Mushtaq, R., Shoib, S., Shah, T., \& Mushtaq, S. (2014). Relationship Between Loneliness, Psychiatric Disorders and Physical Health? A Review on the Psychological Aspects of Loneliness. Journal of Clinical and Diagnostic Research, 8(9), WE01-WE04. 
Noorbakhsh, S. N., Besharat, M. A., \& Zarei, J. (2010). Emotional intelligence and coping styles with stress. Procedia-Social and Behavioral Sciences, 5, 818-822.

Nowland, R., Necka E. A., \& Cacioppo, J. T. (2018). Loneliness and social internet use: Pathways to reconnection in a digital world? Perspectives on Psychological Science, 13(1), 70-87.

Nulty, D. D. (2008). The adequacy of response rates to online and paper surveys: what can be done? Assessment \& Evaluation in Higher Education, 33(3), 301-314.

Nurunnabi, M., Hossain, S. F. A. H., Chinna, K., Sundarasen, S., Khoshaim, H. B., Kamaludin, K., \& Shan, X. (2020). Coping strategies of students for anxiety during the COVID-19 pandemic in China: a cross-sectional study. F1000Research 2020, 9, 1115.

O'Donovan, A*, \& Hughes, B. (2007). Social support and loneliness in college students: effects on pulse pressure reactivity to acute stress. International Journal of Adolescent Medicine and Health, 19(4),523-528.

Özdemir, U., \& Tuncay, T. (2008). Correlates of loneliness among university students. Child and Adolescent Psychiatry and Mental Health, 2(1),1-6.

Park, C. L., \& Fenster, J. R. (2004). Stress-related growth: Predictors of occurrence and correlates with psychological adjustment. Journal of Social and Clinical Psychology, 23, 195-215.

Park, J., Kitayama, S., Karasawa, M., Curhan, K., Markus, H. R., Kawakami, N., \& Ryff, C. D. (2013). Clarifying the links between social support and health: Culture, stress, and neuroticism matter. Journal of health psychology, 18(2), 226-235.

Pijpers, J. (2017). Loneliness among students in higher education: influencing factors. UV Amsterdam. Research Report. Retrieved June 24, 2020 from https://www.huisartsenamsterdam.nl/wp-content/uploads/2017/07/Loneliness Among Students in Higher_Education_Influencing_Factors.pdf

Ramos, Y. (2020). Predictors of Loneliness Among College Students: Evidence for the Necessity of Early Childhood Interventions. Theses/Capstones/Creative Projects, 86, 1-17. https://digitalcommons.unomaha.edu/cgi/viewcontent.cgi?article=1090\&context=univer sity_honors_program

Ren, Y., \& Ji, B. (2019). Correlation Between Perceived Social Support and Loneliness Among Chinese Adolescents: Mediating Effects of Psychological Capital. Psychiatria Danubina, 31(4), 421-428.

Rokach, A. (2018). Effective coping with loneliness: a review. Open Journal of Depression, 7, 6172.

Rubenstein, C. M. \& Shaver, P. (1982). The experience of loneliness. In L. A. Peplau \& D. Perlman (Eds.), Loneliness: A sourcebook of current theory, research, and therapy (pp. 206-223). New York: John Wiley.

Sanders, R. (2020). ESSS Outline: COVID-19, social isolation and loneliness. Special Report Iriss. https://www.iriss.org.uk/resources/esss-outlines/covid-19-social-isolation-and-loneliness

Saunders, M., Lewis, P., \& Thornhill, A. (2016). Research methods for business students. New York: Pearson Education.

Scheier, M. F., Carver, C. S., \& Bridges, M. W. (1994). Distinguishing optimism from neuroticism (and trait anxiety, self-mastery, and self-esteem): a reevaluation of the Life Orientation Test. Journal of personality and social psychology, 67(6), 1063.

Seepersad, S. S. (2001). Analysis of the relationship between loneliness, copping strategies and the Internet [Unpublished doctoral thesis]. University of Illinois, Urbana. USA. 
Segrin, C., \& Passalacqua, S. (2010) Functions of loneliness, social support, health behaviors, and stress in association with Poor Health. Health Communication, 25(4), 312-322.

Sum, S., Mathews, R. M., Hughes, I., \& Campbell, A. (2008). Internet use and loneliness in older adults. CyberPsychology \& Behavior, 11(2), 208-211.

Sundarasen, S., Chinna, K., Kamaludin, K., Nurunnabi, M., Baloch, G. M., Khoshaim, H. B., \& Sukayt, A. (2020). Psychological impact of covid-19 and lockdown among university students in Malaysia: Implications and policy recommendations. International Journal of Environmental Research and Public Health, 17(17), 1-13.

Van Winkel, M., Wichers, M., Collip, D., Jacobs, N., Derom, C., Thiery, E., \& Peeters, F. (2017). Unraveling the role of loneliness in depression: the relationship between daily life experience and behavior. Psychiatry, 80(2), 104-117.

Vasileiou, K., Barnett, J., Barreto, M., Vines, J., Atkinson, M., Long, K., \& Bakwell, L. (2019). Coping with loneliness at University: A qualitative interview study with students in the UK. Mental Health \& Prevention, 13, 21-30.

Wang, J., Mann, F., Lloyd-Evans, B., Ma, R., \& Johnson, S. (2018). Associations between loneliness and perceived social support and outcomes of mental health problems: a systematic review. BMC Psychiatry, 18(1), 1-16.

Xu, J., Ou, J., Luo, S., Wang, Z., Chang, E., Novak, C., \& Wang, Y. (2020). Perceived Social Support Protects Lonely People Against COVID-19 Anxiety: A Three-Wave Longitudinal Study in China. Frontiers in Psychology, 11, 566965.

Yu, H., Li, M., Li, Z., Xiang, W., Yuan, Y., Liu, Y., \& Xiong, Z. (2020). Coping style, social support and psychological distress in the general Chinese population in the early stages of the COVID-19 epidemic. BMC psychiatry, 20(1), 1-11.

Zelin, M. L., Bernstein, S. B., Heijn, C., Jampel, R. M., Myerson, P. G., Adler, G., Rizzuto, A. M. (1983). The Sustaining Fantasy Questionnaire: Measurements of sustaining function of fantasies in psychiatric inpatients. Journal of Personality Assessment, 47, 427-439.

Zikmund-Fisher, B. J., Couper, M. P., \& Fagerlin, A. (2012). Disparities in patient reports of communications to inform decision making in the DECISIONS survey. Patient Education and Counseling, 87(2), 198-205.

Zimet, G. D., Dahlem, N. W., Zimet, S. G., \& Farley, G. K. (1988). The multidimensional scale of perceived social support. Journal of Personality Assessment, 52(1), 30-41. 